\section{In vitro growth and indoleacetic acid production by Mesorhizobium loti SEMIA806 and SEMIA816 under the influence of copper ions}

\author{
Jéssica Dutra Vieira, ${ }^{1}$ \\ Paulo Roberto Diniz da Silva, ${ }^{2}$ \\ Valdir Marcos Stefenon ${ }^{1-3}$
}

${ }^{1}$ Núcleo de Microbiologia Aplicada à Biorremediação, ${ }^{2}$ Núcleo de Cultura de Tecidos Vegetais, ${ }^{3}$ Programa de Pós Graduação em Ciências Biológicas, Universidade Federal do Pampa, Campus São Gabriel, Brazil

\begin{abstract}
The indoleacetic acid produced by symbiotic bacteria is an important phytohormone signaling microbe-plant interaction, being therefore essential for rhizoremediation. In this study, the effect of different concentrations of copper ions on the bacterial growth and indoleacetic acid production was investigated in two strains of Mesorhizobium loti in in vitro conditions, aiming to determine critical concentrations of this heavy metal for rhizoremediation of contaminated soils using this bacterium. The experiment consisted on a control culture without copper and three treatments supplemented with $10 \mathrm{mg} . \mathrm{L}^{-1}, 20 \mathrm{mg} . \mathrm{L}^{-1}$ or $50 \mathrm{mg}$. $\mathrm{L}^{-1}$ of $\mathrm{CuSO}_{4}$. For both strains, the growth stopped after $48 \mathrm{~h}$ and no significant difference was observed across treatments. The production of indoleacetic acid by the control treatment without copper was significantly higher in comparison to the copper-containing treatments. Mesorhizobium loti SEMIA806 and SEMIA816 are resistant to up to $50 \mathrm{mg} . \mathrm{L}^{-1}$ of $\mathrm{CuSO}_{4}$ in the culture medium, presenting effective growth. The synthesis of indoleacetic acid was strongly reduced but not excluded by ions copper in the medium. So, it is expected that environmental copper found in the soil up to the concentration of $50 \mathrm{mg} . \mathrm{L}^{-1}$ will not preclude the symbiotic interaction between $M$. loti and leguminous host plant in rhizoremediation enterprises.
\end{abstract}

\section{Introduction}

In recent years, several approaches for bioremediation have been proposed as alternatives for diminishing environmental heavy metal contamination. ${ }^{1}$ Bioremediation consists on a group of applications, which involves the detoxification of hazardous substances by means of microbes and plants, instead of transferring the pollutants from one substrate to another. Rhizoremediation is a bioremediation method that consists in the enhancement of the metal extraction process through the root system of plants by its association with microbes. ${ }^{1,2}$

For the effectiveness of rhizoremediation, an efficient microbe-plant interaction is needed. The indole-3-acetic acid (IAA) produced by plant-associated microbes is an important phytohormone signaling this interaction. This phytohormone is involved in many processes of nodule formation, such as founder cell specification, nodule initiation and differentiation, vascular bundle formation, and nodule numbers. Therefore, IAA is essential for the formation of the nodules in the roots. ${ }^{3}$ However, sub-lethal levels of copper nanoparticles in the growth medium have been shown to reduce the secretion of secondary compounds by bacteria, including IAA. ${ }^{4}$

Copper is an essential element for all living beings, since it acts as co-factor in several enzymatic reactions. However, exposition to excessive levels of this metal may cause different metabolic problems. In humans, short-term exposure to drinking water contaminated with copper ions may cause gastrointestinal distress, while longterm consumption may cause liver or kidney damage. ${ }^{5}$ Therefore, the bioaccumulation of copper causing toxicity in human, animals and plants is an important issue for environmental health and safety, and rhizoremediation is an important alternative to diminish this problem. ${ }^{1}$

Mesorhizobium loti is a soil and rhizosphere bacteria of agronomic importance due to the nitrogen-fixing symbioses formed with leguminous plants. This species is able to form determinant-type globular nodules and to perform nitrogen fixation on several Lotus species. ${ }^{6}$ In vitro investigations have shown the capacity of this bacterial species for growing in culture conditions with high concentrations of copper (Roll et al., unpublished data), suggesting potential for bioremediation of soils contaminated with this metal. In association with fast-growing legume tree species as Mimosa scabrella (Leguminosae), M. loti may be a quite promissory option for environmental and landscape recuperation in areas polluted with copper, using rhizoremediation. In this study, the interference of different concentrations of copper ions on the bacterial growth and IAA production was investigated in two strains of Mesorhizobium loti in in
Correspondence: Valdir Marcos Stefenon, Av. Antonio Trilha, 1847, São Gabriel, RS, ZIP 97300-000, Brazil.

Tel.: +55.55.3237.0851

E-mail: valdirstefenon@unipampa.edu.br

Key words: Bacterial growth, bioremediation, IAA, rhizobia, rhizoremediation.

Acknowledgements: Authors acknowledge FAPERGS by the PROBIC grant to JDV, UNIPAMPA by financial support and laboratorial facilities, and Dr. Jeferson Luiz Franco who kindly provided technical support for the spectrophotometric analyses.

Contributions: This work was carried out in collaboration among all authors. JDV and PRDS performed the laboratory experiments and wrote the first draft of the manuscript. VMS designed the study, performed the data analysis, supported the laboratory activities and wrote the last draft of the manuscript. All authors read and approved the final version of the manuscript

Conflict of interest: the authors declare no potential conflict of interest.

Received for publication: 5 July 2017

Revision received: 24 July 2017.

Accepted for publication: 8 August 2017 .

This work is licensed under a Creative Commons Attribution NonCommercial 4.0 License (CC BY-NC 4.0).

(C) Copyright J. Dutra Vieira et al., 2017

Licensee PAGEPress, Italy

Microbiology Research 2017; 8:7302

doi:10.4081/mr.2017.7302

vitro conditions, aiming to determine critical concentrations of this heavy metal for rhizoremediation of contaminated soils using this bacterium.

\section{Materials and Methods}

Turfs of Mesorhizobium loti strains SEMIA806 and SEMIA816 were kindly provided by the State Foundation of Agricultural Research of the Rio Grande do Sul (FEPAGRO), São Gabriel, Brazil. The $M$. loti strains were firstly cultured in Petri dishes with solid YM broth (1.0 g.L $\mathrm{L}^{-1}$ yeast extract, 0.5 g.L $\mathrm{L}^{-1} \mathrm{~K}_{2} \mathrm{HPO}_{4}, 0.2$ g.L $\mathrm{L}^{-1} \mathrm{MgSO}_{4}$, 0.1 g.L. ${ }^{-1} \mathrm{NaCl}, 1.0$ g.L $\mathrm{L}^{-1} \mathrm{CaCO}_{3}$ and 10 g.L 1 of D-mannitol). Before bacterial inoculation, the YM broth was solidified with bacteriological agar $\left(15\right.$ g... $\left.\mathrm{L}^{-1}\right)$ and sterilized at $1.2 \mathrm{~kg} \cdot \mathrm{cm}^{-1}$ at $121^{\circ} \mathrm{C}$ for $15 \mathrm{~min}$.

For each strain independently, $1.0 \mathrm{~g}$ of turf was diluted in $100 \mathrm{~mL}$ of saline solution 
$(0.8 \% \mathrm{NaCl}$ dissolved in ultrapure water). Subsequently, $100 \mu \mathrm{L}$ of the dilution from each strain was inoculated in independent Petri dishes with solidified YM broth and cultivated at $28^{\circ} \mathrm{C}$ during $48 \mathrm{~h}$. Actively growing $M$. loti colonies were isolated from this cultures and employed in the analysis of bacterial growth and IAA synthesis in liquid YM broth with copper.

The experiment consisted on a control culture without copper and three treatments: i) YM broth supplemented with 10 mg.L $\mathrm{L}^{-1}$ of $\mathrm{CuSO}_{4}$; ii) YM broth supplemented with $20 \mathrm{mg} . \mathrm{L}^{-1}$ of $\mathrm{CuSO}_{4}$; and iii) $\mathrm{YM}$ broth supplemented with $50 \mathrm{mg} . \mathrm{L}^{-1}$ of $\mathrm{CuSO}_{4}$. Before bacteria inoculation, $20 \mathrm{~mL}$ of the YM broth was dispensed in $300 \mathrm{~mL}$ glass flasks and sterilized at $1.2 \mathrm{~kg} . \mathrm{cm}^{-1}$ and $121^{\circ} \mathrm{C}$ for $15 \mathrm{~min}$. Single colonies were added to the YM broth and incubated for five days at room temperature under 100 RPM shaking.

Bacterial growth was evaluated in each treatment by reading the absorbance of the broth at $560 \mathrm{~nm}\left(\mathrm{OD}_{560} \mathrm{~nm}\right)$ after $0,24,48$ and $120 \mathrm{~h}$ of culture, using a plate reader EnSpire $^{\mathrm{TM}} 2300 \quad$ Multilabel Reader (Perkin-Elmer Inc., USA). The IAA production was estimated after five days of culture. For the estimation of IAA production, the broth was centrifuged at 12,000 RPM for $15 \mathrm{~min}$, the cell-free supernatant reserved and the IAA was estimated spectrophotometrically by mixing $1.0 \mathrm{~mL}$ of the supernatant with $1.5 \mathrm{~mL}$ of the modified ferric chloride-sulphuric acid reagent (1.0 $\mathrm{mL}$ of $0.5 \mathrm{M} \mathrm{FeCl}_{3}, 30 \mathrm{~mL}$ of $\mathrm{H}_{2} \mathrm{SO}_{4}$ and 50 $\mathrm{mL} \mathrm{H}_{2} \mathrm{O}$ ) as described by Gordon and Weber $(1951)^{7}$. The optical density was recorded at $530 \mathrm{~nm}\left(\mathrm{OD}_{530} \mathrm{~nm}\right)$ after 75 min of incubation at room temperature in a dark environment. ${ }^{7}$
Reagents were purchased by SigmaAldrich (St. Louis, USA). All experiments were performed in quadruplicate and the inoculation and sample transfer steps were performed within a sterilized airflow chamber Trox model TLF (Trox Technik, Germany). The statistical significance of the difference among the estimated means for bacterial growth and IAA synthesis was determined using the Mann-Whitney test in the software PAST 3.04. ${ }^{8}$

\section{Results and Discussion}

\section{Bacterial growth}

For both bacterial strains, the growth stopped after $48 \mathrm{~h}$ (Figure 1) and no statistically significant difference $(\mathrm{P}>0.27)$ was observed across treatments in the evaluated periods $(0,24,48$ or $120 \mathrm{~h}$ of culture). However, the bacterial growth revealed different patterns for strains SEMIA806 and SEMIA816 (Table 1 and Figure 1). After
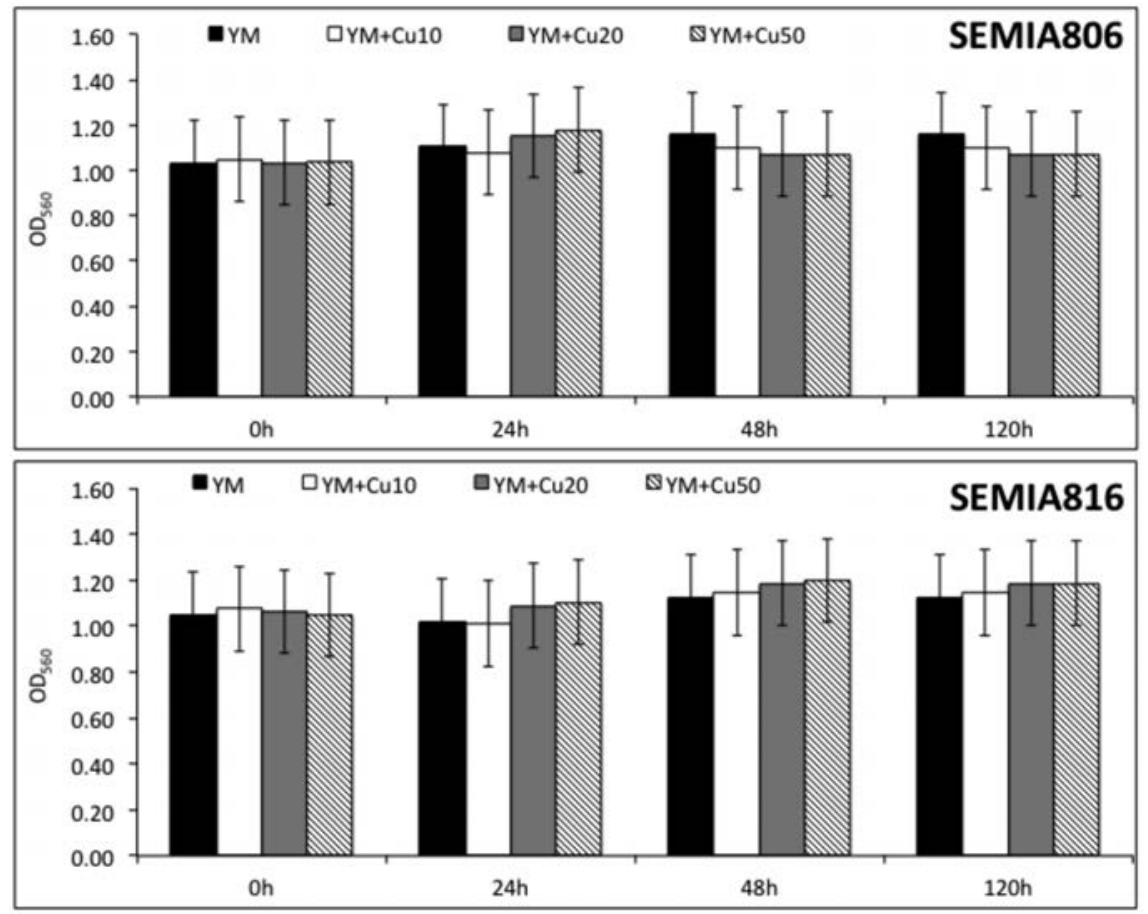

Figure 1. Bacterial growth of M. loti strains SEMIA806 and SEMIA816 cultivated in YM broth without and with addition of copper (YM = YM broth without copper addition; $\mathrm{YM}+\mathrm{Cu} 10=\mathrm{YM}$ broth with addition of $10 \mathrm{mg} . \mathrm{L}^{-1}$ of $\mathrm{CuSO}_{4} ; \mathrm{YM}+\mathrm{Cu} 20=\mathrm{YM}$ broth with addition of $20 \mathrm{mg} \cdot \mathrm{L}^{-1}$ of $\mathrm{CuSO}_{4} ; \mathrm{YM}+\mathrm{Cu} 50=\mathrm{YM}$ broth with addition of $50 \mathrm{mg} \cdot \mathrm{L}^{-1}$ of $\left.\mathrm{CuSO}_{4}\right)$. Values are means over four replicates.

Table 1. Spectrophotometric lectures of bacterial growth at $560 \mathrm{~nm}$ and amount of IAA produced by M. loti strains SEMIA806 and SEMIA816. Values are means over four replicates. The polynomial regression and the corresponding $R^{2}$ values for the growth curve are given for each treatment.

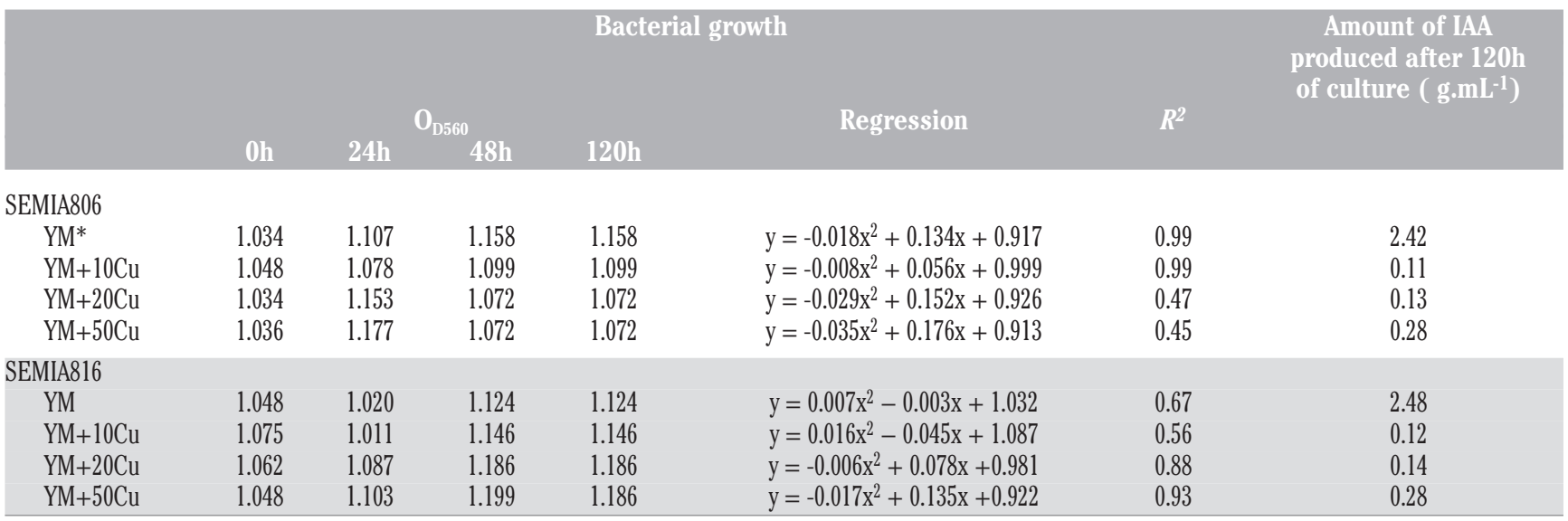

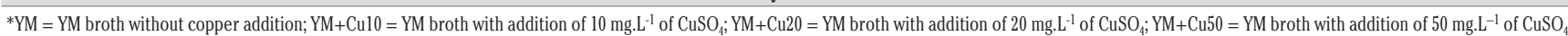


24h of culture, strain SEMIA806 revealed higher growth for treatments with $20 \mathrm{mg} . \mathrm{L}^{-1}$ and $50 \mathrm{mg} . \mathrm{L}^{-1}$ of $\mathrm{CuSO}_{4}$, in comparison to the control without copper and to the treatment with $10 \mathrm{mg} . \mathrm{L}^{-1}$ of $\mathrm{CuSO}_{4}$. At $48 \mathrm{~h}$, treatments with $20 \mathrm{mg} . \mathrm{L}^{-1}$ and $50 \mathrm{mg} . \mathrm{L}^{-1}$ of $\mathrm{CuSO}_{4}$ revealed higher decline in growth. Differently, strain SEMIA816 shown bacterial growth after $24 \mathrm{~h}$ and $48 \mathrm{~h}$ of culture in the treatments with $20 \mathrm{mg} . \mathrm{L}^{-1}$ and $50 \mathrm{mg} . \mathrm{L}^{-1}$ of $\mathrm{CuSO}_{4}$, while the treatment with 10 mg. $\mathrm{L}^{-1}$ of $\mathrm{CuSO}_{4}$ revealed decrease in growth after $24 \mathrm{~h}$ and increased growth after $48 \mathrm{~h}$ of culture (Table 1 and Figure 1).

Former in vitro studies ${ }^{9-12}$ have demonstrated that copper is more toxic than zinc and cadmium, inhibiting the growth of Mesorhizobium at concentrations lower than $20 \mathrm{mg} . \mathrm{L}^{-1}$. The resistance of Rhizobium, Bradyrhizobium, Sinorhizobium and Azorhizobium to copper reached concentrations ranging mostly from 20 to 40 mg.L ${ }^{-1}{ }^{12}$ Many microorganisms demonstrate resistance to metals in water, soil and industrial waste. Genes located on chromosomes, plasmids, or transposons encode specific resistance to a variety of metal ions. ${ }^{13}$ The cop operon responsible by copper resistance has been recorded in Enterococcus hirae, while an operon responsible by copper sequestration with similar nomenclature was described in Pseudomonas. ${ }^{13}$ Such genes can be naturally transferred among bacteria through conjugation and transduction, disseminating this characteristic, which can be quite important for biotechnological purposes. In addition, genetic manipulation can be used to take advantage of metal resistance mechanisms. ${ }^{1}$

The use of microorganisms for the recovery of contaminated areas is an extremely important strategy and has been widely recognized as a very promissory bioremediation method ${ }^{1}$. In that sense, the capacity of growing in a copper-rich environment demonstrated from $M$. loti strains SEMIA806 and SEMIA816 has a significant meaning for the bioremediation of copper-contaminated areas using the rhizoremediation approach.

\section{IAA synthesis}

Different from the bacterial growth, the production of IAA was strongly affected by the copper added to the YM broth. The production of IAA by the control treatment without copper was significantly higher $(\mathrm{P}<0.005)$ in comparison to the copper-containing treatments. The amount of IAA synthesized by the control treatment was from eight to 20 -fold higher than the copper-containing treatments, ranging from 0.11 $\mu \mathrm{g} . \mathrm{mL}^{-1}$ (treatment with $10 \mathrm{mg} . \mathrm{L}^{-1}$ of
$\mathrm{CuSO}_{4}$ ) to $2.42 \mu \mathrm{g} \cdot \mathrm{mL}^{-1}$ (control treatment without copper) for SEMIA806, and from $0.12 \mu \mathrm{g} . \mathrm{mL}^{-1}$ (treatment with $10 \mathrm{mg} . \mathrm{L}^{-1}$ of $\mathrm{CuSO}_{4}$ ) to $2.48 \mu \mathrm{g} \cdot \mathrm{mL}^{-1}$ (control treatment without copper) for SEMIA816 (Table 1). Concerning the copper-containing treatments, the highest production of IAA was observed for the $50 \mathrm{mg} . \mathrm{L}^{-1}$ of $\mathrm{CuSO}_{4}$, followed by $20 \mathrm{mg} . \mathrm{L}^{-1}$ of $\mathrm{CuSO}_{4}$ and $10 \mathrm{mg} . \mathrm{L}^{-}$ ${ }^{1}$ of $\mathrm{CuSO}_{4}$ for both bacterial strains (Table 1). In plants, IAA is involved in multiple growth processes and stress responses. ${ }^{14,15}$ The higher amount of IAA produced by bacteria cultivated under the higher concentration of copper in this study may be response of the microorganisms to stress. Higher amount of exopolysaccharides production by $M$. loti strains SEMIA806 and SEMIA816 under a more stressful environment concerning $\mathrm{pH}$ of the culture media was previously reported. ${ }^{16}$ Similar result concerning exopolysaccharides production under stressful conditions was reported for Bradyrhizobium, Rhizobium, Mesorhizobium, Sinorhizobium and Azorhizobium. ${ }^{12}$ Like the IAA, exopolysaccharides are symbiont derived signals essentials for nodulation in legume-rhizobia symbiosis. ${ }^{17}$ A positive effect of ion copper in the production of IAA by Pseudomonas chlororaphis 06 was also demonstrated. ${ }^{4}$ With the addition of thryptophan to the culture medium, the levels of accumulated IAA after $48 \mathrm{~h}$ was higher than $30 \mu \mathrm{g} \cdot \mathrm{mL}^{-1}$ in cultures with a copper concentration of $43 \mathrm{mg} . \mathrm{L}^{-1}$.

The amount of IAA synthesized by $M$. loti SEMIA806 and SEMIA816 in this study is similar to the extent of IAA produced by different rhizosphere bacteria as Burkholderia phytofirmans ${ }^{18}(0.84 \pm 0.33$ $\left.\mu \mathrm{g} . \mathrm{mL}^{-1}\right)$, Rahnella sp, Burkholderia sp, Pseudomonas sp. ${ }^{19}$ (0.57 to $2.43 \mu \mathrm{g} . \mathrm{mL}^{-1}$; Khan et al. 2016) and 35 unidentified bacteria isolated from soybean in Indonesia ${ }^{20}$ ( 0.051 to $3.208 \mu \mathrm{g} . \mathrm{mL}^{-1}$ ). Considering that all these bacteria were able to interact with the host-plants, the low amount of IAA synthesized by $M$. loti SEMIA806 and SEMIA816 may be sufficient for the establishment of nodules in roots of selected plant species in soils contaminated with copper within the range tested in this study.

\section{Conclusions and perspectives}

Factors such as the culture media employed, growth conditions, and incubation period, besides the various possible forms and concentrations of metals used in the tests of tolerance may difficult their standardization and influence the in vitro toxicity of the metals. Due to these facts there are no universally accepted metal concentrations to define bacterial tolerance or resistance. ${ }^{21}$ However, it is of extreme importance to determine whether the bacterial isolates intended to be used for bioremediation are able to grow under environmental contamination.

The present study demonstrated that $M$. loti SEMIA806 and SEMIA816 are resistant to up to $50 \mathrm{mg} . \mathrm{L}^{-1}$ of $\mathrm{CuSO}_{4}$ in the culture medium, presenting effective growth not significantly different from the control experiment without copper. In addition, it was shown that the synthesis of IAA was strongly reduced but not eradicated by ions copper in the medium. Even though this heavy metal strongly reduced the IAA production for both studied strains of $M$. loti, the amount of hormone synthesis was similar to the quantity produced by different bacterial species able to form nodules in host plants. Therefore, it is expected that environmental copper found in the soil up to the concentration of $50 \mathrm{mg} . \mathrm{L}^{-1}$ will not preclude the symbiotic interaction between M. loti and leguminous host plant species.

As thryptophan is an efficient physiological precursor of auxins, ${ }^{22}$ the presence of this compound in the culture medium improves the bacterial IAA synthesis in vitro. ${ }^{3}$ Therefore, experiments including the amendment of thryptophan to the culture medium should be performed to evaluate the improvement of IAA synthesis by $M$. loti SEMIA806 and SEMIA816 cultivated with copper. In addition, controlled experiments of the interaction plant-bacteria in contaminated soils are needed in order to evaluate the roots' nodulation in such environments, considering also the interaction copper-soil particles as well as the plant synthesis of IAA.

\section{References}

1. Vieira, JD, Stefenon VM. Soil bioremediation in heavy metal contaminated mining areas: a microbiological/biotechnological point of view. J Advances Microbiol 2017; 4:33782

2. Mani D, Kumar C. Biotechnological advances in bioremediation of heavy metals contaminated ecosystems: an overview with special reference to phytoremediation. Int $\mathrm{J}$ Environ Sci Technol 2014;11:843-72.

3. Spaepen S, Vanderleyden, J. Auxin and plant-microbe interactions. Cold Spring Harb Perspect Biol 2011;3:a001438.

4. Dimkpa CO, Calder A, Britt DW, et al. Responses of a soil bacterium, Pseudomonas Chlororaphis O6 to commercial metal oxide nanoparticles com- 
pared with responses to metal ions. Environ Pollut 2011;159:1749-56.

5. Araújo CST, Carvalho DC, Rezende $\mathrm{HC}$, et al. Bioremediation of waters contaminated with heavy metals using Moringa oleifera seeds as biosorbent. In: Patil YB, Rao P, (eds). Applied bioremediation - active and passive approaches, InTech Open Access Publisher, Rijeka, Croatia. 2013. pp 227-255.

6. Kaneko T, Nakamura Y, Sato S, et al. Complete genome structure of the nitrogen-fixing symbiotic bacterium Mesorhizobium loti. DNA Res 2000;7: 331-8.

7. Gordon SA, Weber RP. Colorimetric estimation of indoleacetic acid. Plant Phys 1951;26:192-5.

8. Hammer $\varnothing$, Harper DAT Ryan PD. Past: Paleontological Statistics Software Package for Education and Data Analysis. Palaeont Electr 2001;4:4.

9. Chaudri AM, McGrath SP, Giller KE. Metal tolerance of isolates of Rhizobium leguminosarum biovar trifolii from soil contaminated by past application of sewage sludge. Soil Biol Biochem 1992;24:83-8.

10. Angle JS, Mcgrath SP, Chaudri AM, et al. Inoculation effects on legumes grown in soil previously treated with sewage sludge. Soil Biol Biochem 1993;25:575-80.

11. Trannin ICB, Moreira FMS, Siqueira JO, Lima AS. Tolerância de estirpes e isolados de Bradyrhizobium e Azorhizobium a zinco, cádmio e cobre in vitro. Rev Bras Ciên Solo 2001;25:305-16.

12. Matsuda A, Moreira FMS, Siqueira JO. Tolerância de rizóbios de diferentes procedências ao zinco, cobre e cádmio. Pesq Agropec Bras 2002;37:343-55.

13. Bruins MK, Kapil S, Oehme FW. Microbial Resistance to Metals in the Environment. Ecotoxicol Environ Safety 2000;45:198-207.

14. Krasensky J, Jonak C. Drought, salt, and temperature stress-induced metabolic rearrangements and regulatory networks. J Expt Bot 2012;63:1593608.

15. Shi H, Chen L, Ye T, et al. Modulation of auxin content in Arabidopsis confers improved drought stress resistance. Plant Physiol Biochem 2014;82:209-17.

16. Roll RJ, Vieira JD, Rosa JVS, et al. Exopolysaccharides production by Mesorhizobium loti: effect of carbon source and $\mathrm{pH}$. Am Res J Biosc 2017;3:1-5.

17. Tatsukami Y, Ueda M. Rhizobial gib- berellin negatively regulates host nodule number. Sci Rep 2016;6:27998.

18. Naveed M, Qureshi MA, Zahir ZA, et al. L-Tryptophan-dependent biosynthesis of indole-3-acetic acid (IAA) improves plant growth and colonization of maize by Burkholderia phytofirmans PsJN. Ann Microbiol 2015;65:1381-9.

19. Khan Z, Rho H, Firrincieli A, et al. Growth enhancement and drought tolerance of hybrid poplar upon inoculation with endophyte consortia. Cur Plant Biol 2016;6:38-47.

20. Sahur A, Ala A, Patanjengi B, Syamun E. Isolation and characterization of indigenous rhizosphere bacteria producing gibberellic acid and indole acetic acid from local soybeans in South Sulawesi. Int J Advanc Agric Scien Technol 2017;4:7-15.

21. Lima E, Silva AA, Carvalho MAR, et al. Heavy metal tolerance $(\mathrm{Cr}, \mathrm{Ag}$ and $\mathrm{Hg}$ ) in bacteria isolated from sewage. Braz J Microbiol 2012;43:1620-31.

22. Khalid A, Arshad M, Zahir Z. Phytohormones: microbial production and applications. In: Uphoff N, Ball AS, Fernandes E, et al. (eds). Biological approaches to sustainable soil systems. Boca Raton, Florida: Taylor \& Francis/CRC Press; 2006. pp 207-220. 